\title{
PERBANDINGAN PENGGUNAAN PUPUK ORGANIK CAIR (POC) GEDEBOG PISANG (Musa paradisiaca L) DENGAN PUPUK ORGANIK CAIR (POC) SERABUT KELAPA (Cocos nuciefera L) TERHADAP PERTUMBUHAN TANAMAN JAGUNG MANIS (Zea mays L Saccharata)
}

\author{
1Achmad Baihaki, ${ }^{1}$ Diah Sudiarti, ${ }^{3}$ Imam Bukhori Muslim \\ ${ }^{123}$ Pendidikan Biologi, Universitas Islam Jember \\ 1achmadbaihaky3@gmail.com,2diah.sudiarti23@gmail.com,3imambukhori916@yahoo.co.id
}

\begin{abstract}
ABSTRAK
Jagung Manis adalah salah satu jenis sayuran yang disukai oleh masyarakat karena memiliki rasa yang manis dan enak serta bermanfaat bagi kesehatan karena mengandung banyak gizi, seperti karbohidrat, protein, lemak, beberapa vitamin, dan mineral serta kadar gulanya relatif tinggi. Jenis penelitian ini adalah penelitian eksperimen dengan tanaman jagung manis. Penelitian ini menggunakan rancangan acak lengkap (RAL) dengan pola empat perlakuan. Pemberian POC GP, POC SK, K+ dan K- dengan 3x pengulangan. Berdasarkan hasil penelitian maka diketahui bahwa rata - rata pemberian pupuk kimia terhadap tinggi tanaman Jagung Manis lebih baik dengan rata - rata 60.53 dibandingkan dengan pemberian POC SK rata - rata 57.77dan pemberian POC GP rata - rata 56.47 dan K- rata - rata 43.19. Untuk jumlah daun diketahui bahwa rata - rata pemberian pupuk kimia terhadap jumlah daun Jagung Manis lebih baik dengan rata - rata 6.79 dibandingkan dengan pemberian POC SK rata - rata 6.71 dan pemberian POC GP rata - rata 6.54 dan K- rata - rata 5.74.
\end{abstract}

Kata kunci : Pupuk Organik Cair (POC), Gedebog Pisang (GP) , Serabut Kelapa (SK)

\begin{abstract}
Sweet corn is one type of vegetable that is favored by the public because it has a sweet and delicious taste and is beneficial for health because it contains many nutrients, such as carbohydrates, protein, fat, several vitamins, and minerals as well as relatively high sugar content. This type of research is experimental research with sweet corn plants. This study used a completely randomized design (CRD) with a four treatment pattern. Giving LOF BS, LOF CF, C+ and C- with $3 x$ repetitions. Based on the results of the study, it is known that the average application of chemical fertilizers to the height of Sweet Corn plants is better with an average of 60.53 compared to the average LOF CF 57.77 and the average LOF BS application is 56.47 and $C$ - is average. - average 43.19. For the number of leaves, it is known that the average application of chemical fertilizers on the number of Sweet Corn leaves is better with an average of 6.79 compared to the application of LOF $C F$ an average of 6.71 and the application of LOF BS an average of 6.54 and $C$ - on average - average 5.74.
\end{abstract}

Keywords: Liquid Organic Fertilizer (LOF), Banana Stem (BS), Coconut Fiber (CF)

\section{PENDAHULUAN}

Jagung Manis adalah salah satu jenis sayuran yang disukai oleh masyarakat karena memiliki rasa yang manis dan enak serta bermanfaat bagi kesehatan karena mengandung banyak gizi, seperti karbohidrat, protein, lemak, beberapa vitamin, dan mineral serta kadar gulanya relatif tinggi.
POC adalah pupuk organik yang tersedia dalam bentuk cair, di dalamnya terkandung unsur hara berbentuk larutan sehingga sangat mudah diserap tanaman. POC kebanyakan diaplikasikan melalui daun atau disebut sebagai pupuk cair foliar yang mengandung hara makro dan mikro esensial (N, P, K, S, Ca, Mg, B, Mo, Cu, Fe, $\mathrm{Mn}$, dan bahan organik). POC selain dapat memperbaiki sifat fisik, kimia, dan biologi 
tanah, juga membantu meningkatkan produksi tanaman, meningkatkan kualitas produk tanaman, mengurangi penggunaan pupuk anorganik dan sebagai alternatif pengganti pupuk kandang

POC GP berasal dari tanaman pisang yaitu dari bagian batang/gedebog. Gedebog Pisang memiliki kandungan unsur $\mathrm{P}$ yang bermanfaat menambah nutrisi untuk pertumbuhan dan produksi tanaman (Untung, 2012). Gedebog Pisang harus difermentasikan terlebih dahulu untuk mendapatkan ekstrak Gedebog Pisang yang nantinya dapat digunakan sebagai POC bagi suatu tanaman.

POC SK berasal dari tanaman kelapa yaitu pada bagian buah Kelapa yag di tutupi oleh serabut. Serabut Kelapa dapat dimanfaatkan sebagai POC dengan cara difermentasikan kemudian diambil ekstraknya. Serabut Kelapa mengandung unsur $\mathrm{K}$ yang dapat meningkatkan parameter pertumbuhan. Peranan unsur K dalam pertumbuhan vegetatif tanaman adalah untuk memperbaiki transportasi asimilat, menghemat penggunaan air melalui pengaturan mebuka - menutupnya stomata dan meningkatkan ketahanan tanaman terhadap serangan hama dan penyakit (Mahdiannoor, Istiqomah, dan Syafruddin, 2016).

\section{METODE PENELITIAN}

Jenis penelitian ini adalah penelitian eksperimen dengan tanaman Jagung Manis. Penelitian ini menggunakan Rancangan Acak Lengkap (RAL) dengan pola empat perlakuan. Pemberian POC GP, POC SK, K+ (Mutiara) dan K- (Tanpa Pemberian Pupuk) dengan 3x pengulangan. Pemupukan di lakuakan mulai dari tanaman berumur 10 hst sampai keluar tongkol. Kira-kira setelah berumur 50-60 hari. a. Alat dan Bahan

Alat yang digunakan adalah cangkul, alat ukur, timba, gelas aqua, smartphone. Sedangkan untuk bahan yang digunakan adalah benih Jagung Manis, POC GP, POC SK, K+ pupuk kimia (Mutiara) , K- (tanpa pemberian pupuk)

b. Prosedur kerja

Proedur penelitan dibagi menjadi tiga tahapan: tahapan persiapan, tahapan pelaksanaan, dan tahapan pengamatan.

1. Tahap persiapan.

a. Menyiapkan alat yang akan digunakan dalam penelitian, adapun alat yang digunakan dalam penelitian ini adalah sebagai berikut

- Media Tanah :-

- Cangkul :1 Buah

- Gelas aqua : 1 Buah

- Timba :2 Buah

- Alat ukur/ Meteran :1 Buah

b. Menyiapkan bahan yang digunakan dalam penelitian, adapun bahan yang digunakan dalam penelitian ini adalah sebagai berikut :

1. POC GP

2. POC SK

3. $\mathrm{K}+$

4. K-

2. Tahap pelaksanaan.

a. Penyiapan lahan

Siapkan lahan yang telah dibersikan dari gulma, setelah itu lalu buatlah 4 plot masing - masing lebar $80 \mathrm{~cm}$ dan diberikan kode agar memudahkan dalam penelitian

b. Penanaman

Setelah lahan siap maka buatlah lubang pada plot dengan jarak 
$20 \mathrm{~cm}-25 \mathrm{~cm}$ dan masing - masing lubang diisi 1 benih Jagung Manis

3. Tahap pengamatan.

a. Lakukan pengamatan $1 \mathrm{x}$ perminggu di mulai dari jagung tumbuh sampai berumur 60 hari, lalu catat semua tanda-tandanya. Pengamatan meliputi:

- Pengukuran dan pengamatan dilakukan secara periodik $1 x$ dalam 1 minggu. Meliputi: tinggi tanaman, jumlah daun.

- Tambahan pengamatan: tanaman keluar tongkol pada usia berapa.

- Catat hasil pengamatan di buku tulis dan lembar rancangan percobaan .

\section{METODE ANALISIS DATA}

Dalam penelitian ini data di analisis menggunakan Analysis of Vaeriance (ANOVA) menggunakan SPSS. Uji ANOVA dilakukan untuk mengetahui penggunaan POC efektif terhadap pertumbuhan tanaman Jagung Manis yang meliputi tinggi tanaman, jumlah daun dan tanaman keluar tongkol pada usia berapa dan dilanjutkan dengan uji TTEST untuk mengetahui perbandingan pertumbuhan Jagung Manis lebih cepat yang mana antara penggunaan POC GP dengan POC SK.

\section{PEMBAHASAN}

Penelitian ini tentang perbandingan penggunaan POC GP dan POC SK yang telah dilakukan pada tanggal 3 Februari 2020 sampai 2 April 2020 di lahan Persawahan Glagahwero Kalisat, Jl. Mayangan, Desa. Glagahwero Kec. Kalisat, Kab. Jember, yang berada pada ketinggian antara 100 hingga $500 \mathrm{~m}$ (dpl) sehingga sangat cocok untuk pertumbuhan tanaman jagung manis. Kontur tanahnya lumayan subur dan dekat dengan sungai sehingga lebih mudah untuk proses pengairan. Berdasarkan hasil penelitian dan pengambilan data tersebut diperoleh data sebagai berikut:

\section{Pengamatan terhadap Tinggi Tanaman} Jagung Manis

Tabel 1 Data Tinggi Tanaman Jagung Manis

\begin{tabular}{|c|c|c|c|c|c|c|c|}
\hline $\begin{array}{l}\text { UT } \\
P\end{array}$ & $10 \mathrm{H} 14 \mathrm{H}$ & $24 \mathrm{H}$ & $31 \mathrm{H}$ & $38 \mathrm{H}$ & $45 \mathrm{H}$ & $52 \mathrm{H}$ & $59 \mathrm{H}$ \\
\hline POC GP & 5.713 & 17.78 & 26 & 46.11 & 86.89 & 117.1 & 139.33 \\
\hline POCSK & 6.613 & 18.22 & 29.67 & 45 & 85.11 & 117.9 & 146.67 \\
\hline $\mathrm{K}+$ & 7.115 & 19 & 30.44 & 46.11 & 92.78 & 121.2 & 152.67 \\
\hline K- & 5.312 & 14.78 & 24.11 & 36.67 & 68.22 & 77.89 & 106.33 \\
\hline
\end{tabular}

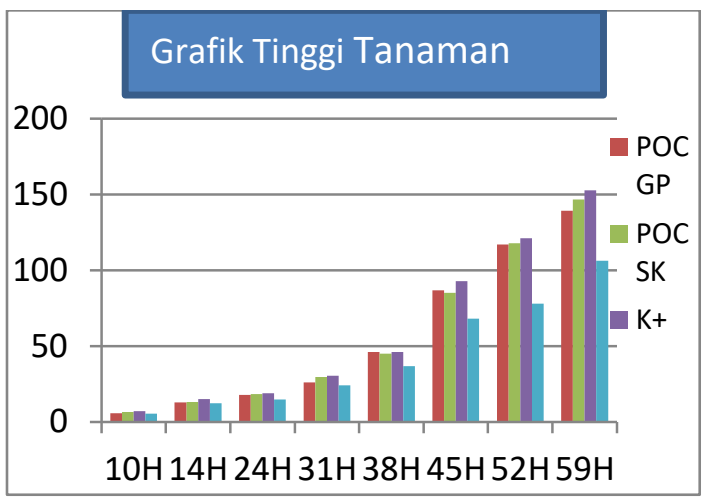

Sumber : Dokumen Pribadi

Gambar 1 Grafik Tinggi Tanaman Jagung Manis

Berdasarkan Tabel 1 diketahui bahwa rata - rata pemberian pupuk kimia lebih tinggi dibandingkan menggunakan pupuk organik yaitu 60.53. Sedangkan antara POC SK lebih baik perkembangannya yaitu 57.77 dibandingkan dengan POC GP yang hanya 56.47 .

Pengamatan terhadap Jumlah Daun Tanaman Jagung Manis. 
Tabel 2 Data Jumlah Daun Tanaman Jagung Manis

\begin{tabular}{|c|c|c|c|c|c|c|c|c|}
\hline $\begin{array}{c}\text { UT } \\
\mathbf{P}\end{array}$ & $10 \mathrm{H}$ & $14 \mathrm{H}$ & $24 \mathrm{H}$ & $31 \mathrm{H}$ & $38 \mathrm{H}$ & $45 \mathrm{H}$ & $52 \mathrm{H}$ & $59 \mathrm{H}$ \\
\hline POC GP & 2.7 & 3 & 4 & 6 & 7.11 & 8.56 & 9.78 & 11.22 \\
\hline POC SK & 2.9 & 2.9 & 4.56 & 6.33 & 7.33 & 8.33 & 10 & 11.33 \\
\hline $\mathrm{K}+$ & 2.8 & 2.8 & 4.89 & 6.44 & 7.33 & 9.22 & 9.78 & 11.11 \\
\hline K - & 2.7 & 2.9 & 4.22 & 4.89 & 5.22 & 7.44 & 8.78 & 9.78 \\
\hline
\end{tabular}

Sumber : Data Pribadi

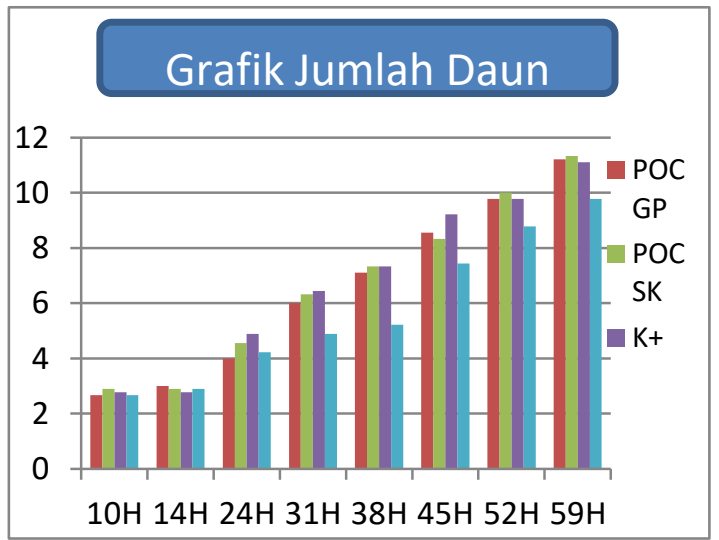

Sumber : Dokumen Pribadi

Gambar 2 Grafik Jumlah Daun Tanaman

Jagung Manis

Berdasarkan Tabel 2 diketahui bahwa rata - rata pemberian pupuk kimia terhadap jumlah daun tanaman Jagung Manis lebih baik dengan rata - rata 6.79, dibandingkan dengan pemberian POC SK rata - rata 6.71, dan pemberian POC GP rata - rata 6.54, dan K- rata - rata 5.74.

\section{Perbandingan Rata - Rata Tinggi} Tanaman dan Jumlah Daun POC GP, POC SK, K+ dan K-

Tabel 3 Data Perbandingan Rata - Rata Tinggi Tanaman dan Jumlah Tanaman Jagung Manis
Rata-Rata

Keseluruhan

\begin{tabular}{lll}
$\begin{array}{l}\text { Tinggi } \\
\text { Tanaman }\end{array}$ & Jumlah Daun \\
\hline $\begin{array}{lll}\text { POC } \\
\text { GP }\end{array}$ & & \\
POC & 56.47 & 6.54 \\
SK & 57.77 & 6.71 \\
K+ & 60.53 & 6.79 \\
K- & 43.19 & 5.74 \\
\hline
\end{tabular}

Sumber : Data Pribadi

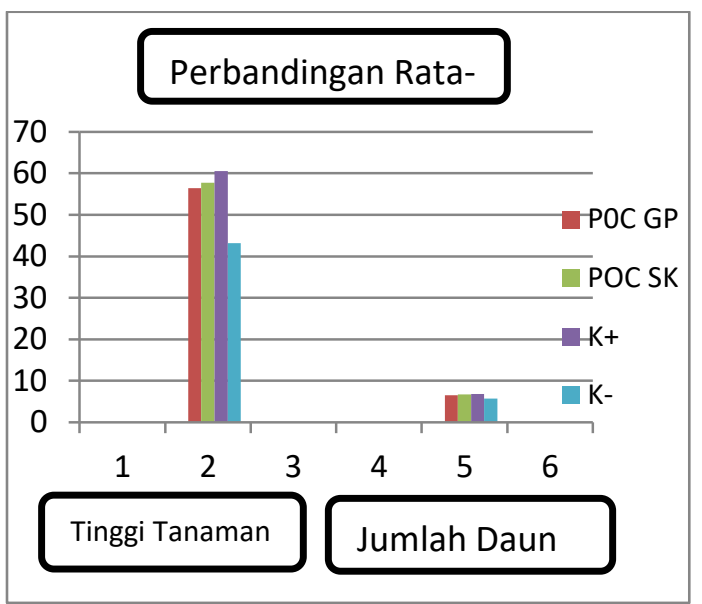

Sumber : Dokumen Pribadi

Gambar 3 Grafik Perbandingan Rata -

Rata Tinggi Tanaman dan Jumlah

Daun Tanaman Jagung Manis

Berdasarkan Tabel 3 diketahui bahwa rata - rata pemberian pupuk kimia terhadap tinggi tanaman Jagung Manis lebih baik dengan rata - rata 60.53 dibandingkan dengan pemberian POC SK rata - rata 57.77 dan pemberian POC GP rata - rata 56.47 dan K- rata - rata 43.19.

Untuk jumlah daun diketahui bahwa rata - rata pemberian pupuk kimia terhadap jumlah daun Jagung Manis lebih baik dengan rata - rata 6.79 dibandingkan dengan pemberian POC SK rata - rata 6.71 dan pemberian POC GP rata - rata 6.54 dan K- rata - rata 5.74 . 


\section{KESIMPULAN}

Berdasarkan hasil penelitian yang telah dilakukan di Desa. Glagahwero Kec. Kalisat Kab. Jember pada tanggal 13 Februari 2020 sampai dengan 2 April 2020 dapat disimpulkan bahwa

a. Pemberian POC GP berpengaruh terhadap pertumbuhan tanaman Jagung Manis

b. Pemberian POC SK berpengaruh terhadap pertumbuhan tanaman jagung manis meskipun tidak sebaik dengan yang menggunakan pupuk kimia,

c. Perbandingan penggunaan POC GP dan POC SK pada tanaman Jagung Manis menunjukkan hasil POC SK lebih baik dari tinggi tanaman maupun jumlah daun

\section{SARAN}

Diharapkan dilakukan penelitian lebih lanjut tentang penggunaan pengaruh $\mathrm{POC}$ ini dengan mengunakan jenis tanaman lain selain Jagung Manis agar mendapatkan hasil yang bervariasi dan dapat menjadikan acuan untuk penelitian selanjutnya.

\section{DAFTAR PUSTAKA}

Ambarwati dkk, 2007. Manfaat Pupuk Organik Cair Untuk Pertumbuhan dan Produksi Tanaman. Jurnal Ilmu Tanah

bappeda.jatim prov 2013 Ketinggian Tanah Kabupaten Jember dan Luas Kabupaten Jember Online http// Ketinggian Tanah Kab Jember/2013/.com di akses tanggal 8 Mei 2020

Ebtan dkk, 2014. Faktor-faktor yang Memengaruhi Pertumbuhan Jagung, Jurnal Produksi Tanaman VoL. 1(6). Hal : 471-477.

Kartasapoetra, 1988. Faktor-faktor yang Memengaruhi Pertumbuhan Jagung, Jurnal Bina Aksara, Jakarta VoL. 18 No. 1.
Mahdiannoor, N., Istiqomah, dan Syafruddin. 2016. Aplikasi Pupuk Organik Cair terhadap Pertumbuhan dan Hasil Tanaman Jagung Manis. Jurnal Ziraa'ah VoL. 41 No. 1 ISNN 2355 - 3545

Rachman, I. A., S. Djuniwati, dan K. Idris. 2008. Pengaruh Bahan Organik dan Pupuk NPK terhadap Serapan Hara dan Produksi Jagung di Inceptisol Ternate. Jurnal Tanah dan Lingkungan.

Risnah, S., P. Yudono, dan A. Syukur. 2013. Pengaruh Abu Sabut Kelapa terhadap Ketersediaan K di Tanah dan Serapan K pada Pertumbuhan Tanaman. Jurnal Ilmu Pertanian.

Riwandi, M. Handajaningsih, dan Hasanudin. 2014. Teknik Budidaya Jagung dengan Sistem Organik di Lahan Marjinal. Unib Press. Universitas Bengkulu. $67 \mathrm{hlm}$.

Rubatzky, V.E.,dan M. Yamaguchi. 1998. Sayuran Dunia: Prinsip, Produksi dan Gizi, Jilid 1. Bandung. Penerbit ITB.

Nasaruddin dan Rosmawati. 2011. Pengaruh Pupuk Organik Cair (POC) Hasil Fermentasi Daun Gamal, Batang Pisang dan Sabut Kelapa terhadap Pertumbuhan Bibit Kakao. Jurnal Agrisistem.

Rachman, I. A., S. Djuniwati, dan K. Idris. 2008. Pengaruh Bahan Organik dan Pupuk NPK terhadap Serapan Hara dan Produksi Jagung

Suprihatin. 2011. Proses Pembuatan Pupuk Cair dari Batang Pohon Pisang. Jurnal Teknik Kimia.

Sutarya. dkk 1995. Pedoman Bertanam Sayuran Dataran Rendah. UGM-Press, Yogyakarta.

Syukur, M., dan A. Rifianto. 2014. Bertanam Jagung Manis. Jakarta. Penerbar Swadaya.

Sutaryana dkk., 1995. Pengaruh Iklim terhadap Pertumbuhan Tanaman Jagung. Pusat Penelitian Tanamn Pangan, Bogor.

Thomas dkk. (2013). Kandungan Sabut Kelapa yang Mengandung Unsur K yang dapat 
Meningkatkan Parameter Pertumbuhan. Gadjah Mada University Yogyakarta

Untung, 2012. Kandungan Batang Pisang Memiliki unsur $P$ yang Bermanfaat Menambah Nutrisi. untuk Pertumbuhan dan Produksi Tanaman. Skripsi S1 pada Universitas Hasanuddin, Makassar. 